\title{
SOCIAL MEDIA AND “CROOKED” POLITICAL DISCOURSE
}

\author{
Ronald E. Day \\ Department of Information and Library Science, Indiana University-Bloomington \\ roday@indiana.edu
}

\begin{abstract}
This paper examines the relation of social media to political discourse in light of Bruno Latour's notion of political discourse being (innately and positively) "crooked" (se courber) in his book, An Inquiry into Modes of Existence: An Anthology of the Moderns. In this book, Latour argues for a geometry of political rhetoric and its claims to truth that is the reverse of the Western philosophic tradition's. This article looks at that geometry from the aspect of rhetorical strategies of fragment and punctuation, empowered by the form and use of social media. It examines such in the presidential campaign of Donald Trump in the United States of America during 20152016. Contrasts and connections to earlier, 'old media,' mediums and technologies, such as that of modern journalism and radio are made.
\end{abstract}

Key words: Social Media. Political discourse. Truth. Rhetoric.

\section{AS MIDIAS SOCIAIS E O "CURVO" DISCURSO POLÍTICO}

\begin{abstract}
Resumo
Este trabalho analisou a relação entre o discurso político e as mídias sociais à luz da noção do discurso político como sendo (inata e positivamente) "curvo" (se courber), entendimento de Bruno Latour em seu livro "Investigação sobre os modos de existência: uma antologia dos modernos". Neste livro, Latour argumenta acerca de uma geometria da retórica política e suas reivindicações à verdade, que é o reverso (diversa) da tradição filosófica ocidental. Esta artigo examina esta geometria a partir de estratégias retóricas pontuais e fragmentadas, empoderadas pela forma e uso das mídias sociais. Examinou-se esta relação na campanha presidencial de Donald Trump nos Estados Unidos da América, durante 2015-2016, e os contrastes e conexões em relação a como eram feitas nas anteriores mídias e tecnologias 'velhas mídas', como o jornalismo moderno e o rádio.
\end{abstract}

Palavras-chave: Mídias sociais. Discurso político. Verdade. Retórica.

\section{Introduction}

In Bruno Latour's recent book, An Inquiry into Modes of Existence (LATOUR, 2013), Latour discusses political discourse as a discourse that is heavily inflected by the site specificity and time value of the enunciation, so that is composed of a "continual renewal" of enunciation through an appeal and dialogue with the audience. One may say that Latour is addressing what Antonio Negri earlier (HARDT; NEGRI, 2000; NEGRI, 2003) described as political discourse at the site and time of the kairos of the speaker's enunciation, though 
significantly, Latour, unlike Negri, finds this discourse as not being structured by an originary "naming" of site-specific and time-valued interests of a multitude, but rather its specificity is characterized by a repetition or a "continual renewal or reprise of a movement that cannot rely definitively on anything [...] and it explains the choice of the adjective 'crooked' [se courber]" (LATOUR, 2013, p. 134).

One question that social media poses to political discourse is that of the sociotechnical temporal and spatial dimensions of the polis of need. Social media are very sensitive to this question, as they at least seem to function as communicative spaces primarily, and information spaces secondarily. After all, it is social media. But as I will show, this may be illusionary, based more on the social or the cultural elements - including previous media - that are included in, and what lies at the points of reception for, social media postings. As made up of postings, social media retains a documentary basis - a representational rhetorical form, documentary techniques for indexing and retrieval, as well as a philosophy of evidence that reaches back to the beginnings of the rhetoric of truth in Western philosophy and culture. But social media is also a very particular kind of documentation because of the formal qualities of its posts and also because of its social functions, namely which has qualities in some ways like journalistic news, and so is a receptive ground for absorbing such, and in other ways are conversational-communicative, which make it largely neither journalistic nor obviously documentary. Further, it is not a medium where there exist strong claims of documentation to 'fix' or make permanent information (even less so than in journalism). And so social media are a mixed communicative and information/documentary media form when viewed against older media.

However, social media 'news' and what we have traditionally called journalistic news reporting can converge at the point of the immediacy of what is considered to be new. The very brief rhetorical format of both journalism articles and social media postings give value to the existential and performative formation of statements above the essentialist claims of more scholarly or archival documents, even when these latter are used in reporting the news. And within a metaphysics and philosophy of what I call 'documentarity' - a metaphysics and epistemology of representational evidence - such temporality is viewed with distrust as the site of truth.

To get at these issues, I'd like to examine a central aspect of the notion of political discourse in Bruno Latour's book, An Inquiry into Modes of Existence (LATOUR, 2013). The authorized translation of Latour's se courber as "crooked" might be more accurately translated as 'bent' or, as we will use here, 'curved.' However, the authorized English 
translation does echo Latour's (2013) cynicism regarding the desire of the "multitude" for the direct expression of their will in law and, conversely, his relatively favorable explanation of why politicians may be honest in the performance of their "crooked" discourse.

For Latour (2013), the central fallacy of democracy consists in the belief that political discourse should imitate truth in philosophy, which Latour sees as taking the rhetorical and epistemological form of 'direct' or 'straight' discourse. This leads him, for example, to favorably contrast sophistic discourse with Plato's disparagement of the sophists and to criticize Plato's valorization of geometry as a model for philosophical reasoning. With this, Latour makes a direct link between rhetorical form and political claims to truth, suggesting that if we don't take account of the innate crookedness of political discussion then we can't evaluate its speaker's truth claims and the honesty of the speaker very well. As Latour writes,

[...] political reasoning never goes straight: this is what scandalizes, and what the Moderns keep trying to rectify with prostheses. They want it to be straightforward, flat, clean; they want it to tell the truth [....] This began with Socrates and has never stopped, through Hobbes and Rousseau, Marx and Hayek, to Habermas. (LATOUR, 2013, p. 333)

For Latour, politics emerges from political discourse through what he calls the "Circle of representation" or "the political Circle" (LATOUR, 2013, p. 343 and 344). This "Circle" contrasts with both authoritarian views to truth on behalf of the governing (where their beliefs go 'straight' to truth) and the cynical views of the governed (where the actions of politicians go 'straight' to falsity by virtue of not going directly to truth). The Circle of politics consists of an opinionated, complaining "multitude" that are subsequently brought into increasingly "unified version[s]" of opinions through "requirements, orders and laws" over time, as this process is repeated again and again. The Circle starts over and over again until it reaches a more unitary nature of a political state, as the multitude - hopefully now "more confident, more reassured, more protected" - then invests further into the process of representational politics and obeys the laws more fully. The Circle may also expand or contract,

[...] include more, or exclude more, depending on the number of people it manages to represent faithfully (by translating/betraying them through and through) and on the number of those whose obedience it secures (and these are the ones, this time, who betray/translate what is expected of them) (LATOUR, 2013, p. 333).

For the purposes of this essay, I'll refrain from a critique of Latour's explanation or model of democracy, which I find to be quite naïve and elitist. Rather, I will focus on how we 
could read political discourse on social media, in terms of the rhetorical curves that exist within and emerge out of it as a sociotechnical and rhetorical form.

Certainly anyone interested in a discussion of curves or other geometries of political discourse within recent French critical thought must acknowledge Althusser's "rain" of the multitude and their transversal collisions in his very last notes on a "politics of the encounter" (ALTHUSSER, 2006), where Althusser cites the rain of atoms in Book II of Lucreatius's De Rerum Natura. The Althusserian rain of politics is something less than straight - a rain of individual and collective wills, choices, and fates that blow around and cause the collision of the individual atoms of human beings and add uncertainty to their political affairs. Within such a rain, political philosophy has problematic predictive and prescriptive powers.

Recently, with the retreat of IndyMedia, Wikileaks, and alike, along with the retreat of street protests such as Occupy Wallstreet in the face of government media and political repression in the US, Italy, and in other so-called 'democratic' countries at the end of the 1990s and early $21^{\text {st }}$ century, and the reconsolidation of the internet by corporate portals and news aggregators, the 'old [news] media' seems to making quite a comeback on the internet.

The modern journalistic press is primarily a documentary medium, and as such is rhetorically characterized by a representationalist style of presentation. The press tells you what recently happened or is now happening and what the authoritative commentary is on it; at most, one has a chance to comment on this by letters to the editor or such, with requires the permission of the newspaper or other press medium, of course. As a documentary rhetoric and medium, the press literally presses flat the live exchanges of candidates and the multitude into a documentary reporting of a represented event. Actions become events in the press in so far as they are represented, and they are chosen and framed as represented events, so as to report — or give evidence — of something other than the event itself.

As a documentary medium, the press presents events as evidence, not only of the events themselves, but more importantly and perhaps less seen, as their being considered actions worth reporting as an event. If events are 'pressed flat' in the geometry of old media journalism, there are two planes for this: that of events (or evidence) and that of truth (or meaning). The 'stories' of the news may lie in the events of the actions in such, but their appearance as news - as what is new - lies in their being evidence for what is - from the viewpoint of the press and possibly others - worth reporting. The events that are reported tell us what is worth reporting; they represent essential values. For example, one cannot simply reduce such events as the endless political campaigns in the US presidential elections to being only spectacles; rather, they are spectacles of something. This is what gives them their 
documentary character and their importance as news stories, just as supposedly in scholarship a document gives evidence of something that could be considered to be a fact or in the Aristotelian tradition of science beings give evidence of the idea of an essence of a being (a particular rabbit as being evidence of some ideal morphological form, ancestral genus, or genetic code of 'rabbitness,' for example).

We generally think of social media as having a different documentary weight than scholarly or scientific information. It also seems to have a different, at times lesser, documentary weight than journalism, too. It is not a medium where "direct news reporting" is assumed to take place, but where news is inflected in a conversational context, even when it does directly report the news. Social media is at least heralded as being a site of possible conversation and argument, much in the same way as Latour's (2013) notion of political discourse is supposed to trace a site of rhetorical curves and bends in public space - i.e., conversation, and in this sense, 'communication,' in the agora. (Though one could also suggest that on social media these curves are technologically straightened out, extended, and shrunk by means of vectors and silos, literally by the application of graph theory in indexing and recursive techniques in searching).

If social media is at least ostensibly distinguished from traditional documentation and the metaphysics of documentarity by its having an innate conversational or communicational curve or even circularity and not being locked into a 'direct' mode of representational truth, then what affect does old media - based on the epistemological assumptions of documentary evidence, representation, and rhetorical 'directness' or 'straightness' - have upon it when incorporated within social media's technological sphere?

Political discourse that takes place on social media often relies upon journalistic reporting. When it is based on investigative reporting, journalistic news can have great historical and social depth, and it can provoke the desire for more information and explanation. There is no replacement for it. Unfortunately, investigative reporting often doesn't get done today, due to media consolidation and corporate ownership, reduced newsroom spending, part-time labor at news businesses, low interest in investigative reporting in journalism schools, and a 24-hour news cycle. Instead, what we mostly have with 'news' is the evidence of events and persons in their immediacy, selected for impact value upon the audience or for tie-in with other media stories, ideological agendas, or infotainment in support of the other corporate arms of the media owner. In short, the public is largely given the spectacle of the new, as both performative and representational evidence of 'what is.' 
With the short character count of textual postings that are available on social media, the news, as a spectacle, finds a familiar home on the newer medium of the new, social media. Though social media is a distinctly communicative medium, it is also a documentary mode of communication - its participants post, rather than truly converse as in oral conversation. Its participants have plenty of time to take stands in such posts, rather than be absorbed in the play of conversation. The addition of rhetorical forms from old media, which largely depend on documentary techniques, further shifts social media toward the political dynamics and social forms of old media.

Like Ronald Regan and Silvio Berlusconi before him, an old media and television personality such as the Republican presidential nominee, Donald Trump, is well versed in media that display rapidly changing truth claims in the midst of a consistency of general tone. $\mathrm{He}$ is well versed in the techniques of spectacle. He easily rides the waves of changing details while maintaining a consistency in tone, like a character on aTV show. Like a TV show, he returns to a theme, over and over again, starting anew, leaving us with glittering episodes or fragments whose relation to realities is spotty and tangential. He mixes in sensationalism with what is truly known. He is sort of the 'bad' version of Latour's discursive refrain in political discourse, because his discursive returns take place in a medium where his previous points are either forgotten or forgiven in the very "crookedness" that, ironically, Latour finds natural to the democratic space.

Trump's performance demonstrates how easily political discourse can slide from communicative crookedness to documentary fragmentation and back again in a medium dominated by forgetting. His rhetorical strategy of punctuating arguments with fragments of mixed true and false 'facts' can find little response within a rhetorical tradition that locates truth in extended argument. It's like trying to combat comic sarcasm by the very argument that it is being used against. There's not a good model that I know of in the Western rhetorical tradition for combating such rhetorical punctuation when there is neither time nor effort at fact checking. Like fascist rhetoric in earlier modern ages, a medium of fragmentation (then radio, now television and press news cycles and social media) empowers its sharp edges. Through Twitter and alike, Trump has utilized rhetorical fragmentation and punctuation as a weapon of (and against) truth.

Social media can also be used by political campaigns as a testing ground for their political rhetoric, independent or together with old media. 'Stories' are posted online and then commented upon (sometimes by campaign operatives themselves) in social media, and these are then 'uploaded' to Press articles. Trump has shown how Twitter statements - themselves 
the epitome of shimmering rhetorical fragments of the new-can be used against opponents (and sometimes against old journalistic media as well), utilizing the very lack of analytic depth inherent to the formal quality of Twitter 'tweets' as a means to avoid analysis and, instead, to engage in and feed into journalistic 'controversy.' By the time such Twitter claims or tropes can be disproved or unpacked, the news and its audience has moved on to the next fragments being posted.

In sum, social media's relation to "crooked" or curved talk in democratic politics is ambiguous because it is torn between information-documentary media and conversationalcommunicational media. Social media is not rhetorically or epistemologically 'ultra-straight,' in the sense of the claims of archival or scholarly documentation to represent truth 'factually' or in-depth, but it does have some of the same 'straightness' or 'directness' in its rhetorical form as journalistic news does, and it shares with the latter a fixation on the immediate or new. Further, social media is organized by computational techniques that promote indexing and retrieval by linear inferences and recursive and categorical groupings. So, in all these senses, social media has the documentary relation to truth that Latour finds to be antithetical to a true understanding of political discourse. On the other hand, it is clearly 'social,' and so, 'bent' or curved by virtue of being a conversational or communicative forum.

In terms of the originality of value of social media content creation and reception in the political sphere, social media highly depends upon the other, social and cultural forces, pulling upon it and organizing it. Social media is created through the interaction of sociocultural and technological poles that are dialectically brought together so as to create meaningful identities, expressions, and values on the internet (DAY, 2014).

Perhaps the greater, new, promise of social media than that of content creation in the political sphere is as an organizing tool for political action. The internet is most politically powerful when drawn out of its documentary sphere, when its information is recovered and discovered in more complex material spaces than that of documentary representation. Here, the newness of social media postings and conversations come to be repositioned in political formations that are more multiple and contradictory than documentary forms and statements can be. Here is the site of the multitude - not the organized space of documentary representation, either linear or curved. Reorganizing for this site of politics has been the role of all radical documentary production, discourse, and communication in modernity. If one wants to experience the Althusserian rain, one can look online, but then one must go outside.

The terms of political struggle have been largely the same in modernity for the past hundred and fifty years, but ideology today faces much larger challenges to its monopoly 
upon knowledge than ever before, thanks to what is online. Cultural institutions should be empowering social media as a tool of organization, and democratic political institutions should be increasing the ability of students to network with one another toward becoming political forms of power, instead of confining them to being media spectators.

Instead, what we see is the continual battle for control over the power of a social 'internet,' with old media and old politics trying to appropriate and leverage the formal means of newer media. The aesthetics of fascism in the age of new information and communication technologies when Walter Benjamin was writing in the 1920s and 30s are not so different than now, as new media communicative technologies still utilize the abbreviated documentary techniques of that time within a politics not so distinguished from that time. While we have new, or rather, newer, mediating technologies of information and communication, ideologies and institutional socio-cultural traditions and personal habits largely have not changed. Technological mediation bends around personal needs and expressions.

Social media is part of the social; its technologies index social needs through computationalized cultural forms. How the social is characterized politically is the key that

will either unlock or remediate social media as a medium of political change. The internet has changed the stakes for how the political may be remembered as knowledge, and this documentary change may exert enough influence to change the cultural institutions (for good or bad, toward more 'enlightenment or more prejudice and fascism), or cultural institutions may reassert control through the aesthetic devices of social media and the politics of beliefs and force that best serve them.

The Althusserian rain continues to fall in modern civilizations, perhaps harder now than in recent memory, and the progressive values of social media in this storm lie in more than their technological competencies.

\section{References}

Althusser, L. (2006). Philosophy of the encounter: later writings, 1978-87. London ; New York: Verso.

Day, R. E. (2014). Indexing it All: The Subject in the Age of Documentation, Information, and Data. Cambridge, Mass.: MIT Press.

\section{Referências}

ALTHUSSER, Louis. Philosophy of the encounter: later writings, 1978-87. London ; New York: Verso, 2006.

DAY, Ronald E. Indexing it all: the subject in the age of documentation, information, and data. Cambridge, Mass.: MIT Press, 2014. 
Hardt, M., \& Negri, A. Empire. Cambridge, HARDT, Michael; NEGRI, Antonio.

Mass.: Harvard University Press, 2000.

Latour, B. An inquiry into modes of existence: an anthropology of the moderns. Cambridge, Massachusetts: Harvard University Press, 2013.

Negri, A. "Kairos, Alma Venus, Multitudo". In Time for Revolution, London: Continuum, 2003.
Empire. Cambridge, Mass.: Harvard University Press, 2000.

LATOUR, Bruno. An inquiry into modes of existence: an anthropology of the moderns. Cambridge, Massachusetts: Harvard University Press, 2013.

NEGRI, Antonio. Kairos, alma Venus, multitudo. In. Time for revolution. London: Continuum, 2003. 